\title{
STUDI SIFAT FUNGSIONAL DAN KIMIA TEPUNG KECAMBAH KACANG KORO BENGUK (Mucuna pruriens L.)
}

Study of Functional and Chemical Properties of Mucuna Bean Sprout Flour (Mucuna pruriens L.)

\author{
Vivian Citra Liadi ${ }^{1)}$, Ni Wayan Wisaniyasa ${ }^{2}$, Ni Nyoman Puspawati ${ }^{2}$ \\ ${ }^{1)}$ Mahasiswa Program Studi Imu dan Teknologi Pangan, Fakultas Teknologi Pertanian, Unud \\ ${ }^{2}$ Dosen Program Studi Imu dan Teknologi Pangan, Fakultas Teknologi Pertanian, Unud \\ Kampus Bukit Jimbaran, Badung-Bali
}

\begin{abstract}
The purpose of this study was to determine the functional and chemical properties of mucuna bean sprout flour. This study was conducted using 48 hour germination and without germination of mucuna bean, and each treatment was repeated three times. Mucuna bean flour and mucuna bean sprouts flour were tested for rendemen, functional properties (water absorption, oil absorption, swelling volume, and solubility), and chemical properties (moisture content, ash content, protein content, fat content, carbohydrate content, and HCN content). The results showed that germination of mucuna bean had a very significant effect on rendemen, water absorption, oil absorption, ash content, moisture content, a significant effect on fat content, carbohydrate content, and had no significant effect on swelling volume, solubility, protein content, and HCN content. The results showed that rendemen of mucuna bean sprout flour was $63.93 \%(\mathrm{db})$, the functional properties of mucuna bean sprout flour were water absorption $1.67 \mathrm{ml} \mathrm{H2O} / \mathrm{g}$ solid, oil absorption $2.17 \mathrm{ml}$ oil/g solid, swelling volume $8.68 \mathrm{ml} / \mathrm{g}$, and solubility $25.76 \%$, while the chemical properties of mucuna bean sprout flour were water content $8.10 \%$, ash content $2.87 \%$, protein content $36.33 \%$, fat content $10.77 \%$, carbohydrate content $41.92 \%$, and $H C N$ content $5.39 \mathrm{mg} / \mathrm{kg}$.
\end{abstract}

Keywords : mucuna bean, mucuna bean sprout flour, functional properties, chemical properties

\section{PENDAHULUAN}

Kacang koro merupakan tanaman yang termasuk dalam polong-polongan dan makanan sumber protein dan minyak nabati. Salah satu jenis kacang koro yang dapat dimanfaatkan sebagai bahan baku dalam adalah kacang koro benguk. Menurut Syam (2003), produktivitas kacang koro benguk di Indonesia cukup tinggi mencapai 0,51 ton biji per hektar. Kacang koro benguk juga tergolong salah satu jenis kacang lokal yang belum dimanfaatkan secara maksimal. Sementara itu, kendala yang dihadapi dalam pengolahan biji kacang koro benguk adalah adanya asam sianida.

\footnotetext{
*Korespondensi Penulis:

E-mail: viviancitra@gmail.com ${ }^{1)}$
}

Asam sianida merupakan salah satu jenis senyawa antigizi. Berdasarkan SNI 01-71522006 tentang bahan tambahan pangan persyaratan perisa dan penggunaan dalam produk pangan, batas maksimum sianida dalam produk pangan yang mengandung jenis kacang dan umbi adalah $50 \mathrm{mg} / \mathrm{kg}$ (Anon., 2006). Senyawa zat antigizi seperti asam sianida, asam fitat, antitripsin, dan senyawa antigizi lainnya pada kacang-kacangan dapat diturunkan dengan cara perkecambahan. Menurut Kristianto (2013), perkecambahan kacang koro benguk selama tiga hari mampu menurunkan kandungan asam sianida. Selain itu, perkecambahan selama 24-72 jam dapat menurunkan aktifitas antitripsin sebanyak 29- 
$46 \%$ dan mampu meningkatkan sifat fungsional seperti daya serap air dan kelarutan pada tepung kecambah kacang gude (Wisaniyasa et al., 2015). Penelitian lainnya juga menyatakan bahwa perkecambahan pada kacang merah dapat meningkatkan kandungan gizi seperti kadar abu, kadar protein, kapasitas antioksidan, dan daya cerna protein (Wisaniyasa dan Suter, 2016; Wisaniyasa et al., 2017).

Setiap kacang memiliki perbedaan waktu perkecambahan. Berdasarkan hasil penelitian, waktu perkecambahan terbaik pada kacang koro benguk selama 48 jam, kacang tunggak selama 36 jam, kecipir selama 24 jam, dan kedelai hitam selama 36 jam (Khairi dan Kanetro, 2014). Penelitian lainnya juga menyatakan bahwa perkecambahan kacang koro benguk selama 0-72 jam menghasilkan waktu perkecambahan terbaik yaitu selama 48 jam karena terjadi kenaikan kadar protein total yang tertinggi sebesar 31\% dengan kadar air sebesar 60,27\% (Kanetro dan Dewi, 2010).

Pemanfaatan kecambah kacang koro benguk masih terbatas sehingga pengolahan yang dapat dilakukan adalah dengan cara penepungan. Teknologi tepung dipilih karena memiliki beberapa keunggulan, yaitu penanganannya lebih mudah dalam pengolahan maupun penyimpanan. Pengolahan pangan yang menggunakan tepung perlu mengetahui sifat fungsional karena sifat fungsional mempengaruhi komponen dalam makanan selama persiapan, pengolahan, penyimpanan, dan konsumsi (Metirukmi, 1992) serta sifat kimia mencakup kandungan gizi dari tepung tersebut. Sampai saat ini belum terdapat penelitian mengenai pengaruh perkecambahan terhadap sifat fungsional dan kimia tepung kecambah kacang koro benguk. Oleh karena itu, penelitian ini dilakukan dengan tujuan untuk mengetahui sifat fungsional dan kimia tepung kecambah kacang koro benguk.

\section{METODE PENELITIAN}

\section{Tempat dan Waktu}

Penelitian dilaksanakan di Laboratorium Pengolahan Pangan dan Laboratorium Analisis Pangan di Jalan P.B. Sudirman, Denpasar. Laboratorium Biokimia Pangan Fakultas Teknologi Pertanian, Universitas Udayana di Bukit Jimbaran. Penelitian dilakukan dari bulan Juli sampai Agustus 2018.

\section{Bahan dan Alat}

Bahan utama adalah kacang koro benguk kering berwarna belang dengan umur panen 5 bulan. Bahan kimia adalah aquades, minyak kedelai, $\mathrm{H}_{2} \mathrm{SO}_{4}, \mathrm{NaOH}, \mathrm{HCl}$, tablet Kjeldahl, heksan, alkohol 96\%, asam borat, KI 5\%, $\mathrm{NH}_{4} \mathrm{OH}$, dan $\mathrm{AgNO}_{3}$.

Alat yang digunakan adalah baskom, plastik, blender merek philips, timbangan analitik (Shimadzu), keranjang, daun pisang, kompor, oven (Cole Parmer Stableterap), kertas saring, ayakan 60 mesh, erlenmeyer, cawan porselin, tabung sentrifuge, sentrifuge (Centurion Scientific), vortex (Maxi Mix II), desikator, alumunium foil, corong, pipet tetes, labu takar, hot plate, buret, muffle, neraca analitik, pendingin balik, destilator, gelas ukur (Phyrex), gelas beaker (Phyrex), erlenmeyer (Phyrex), pipet volume, labu kjeldahl, soxhlet, dan waterbath.

\section{Rancangan Percobaan}

Metode percobaan yang dilakukan secara eksperimen dengan perlakuan tanpa perkecambahan (F1) dan perkecambahan selama 48 jam (F2). Perlakuan diulang sebanyak 3 kali sehingga diperoleh 6 unit percobaan. Perbedaan rendemen, sifat fungsional, dan kimia diuji dengan uji $\mathrm{T}$ berpasangan (Steel and Torrie, 1995).

\section{Pelaksanaan Penelitian}

Tahap 1 pembuatan tepung kacang koro benguk yaitu mengambil sebanyak 150 gram kacang koro benguk yang sudah disortasi kemudian direndam selama 24 jam dan 
ditiriskan. Proses penepungan dilakukan dengan mengoven kacang koro benguk pada suhu $50^{\circ} \mathrm{C}$ selama 24 jam, kemudian diblender, dan diayak menggunakan ayakan 60 mesh (Anita, 2009 yang dimodifikasi). Tahap 2 pembuatan tepung kecambah kacang koro benguk yaitu mengambil sebanyak 150 gram kacang koro benguk yang sudah disortasi kemudian direndam selama 24 jam dan diletakkan ke dalam wadah plastik dengan beralaskan dan ditutup dengan daun pisang. Kacang dikecambahkan selama 48 jam dengan disemprot air sebanyak $10 \mathrm{ml}$ tiap 12 jam. Kecambah kacang koro benguk dioven dengan suhu $50^{\circ} \mathrm{C}$ selama 24 jam dan diblender serta diayak menggunakan ayakan 60 mesh (Anita, 2009 yang dimodifikasi).

\section{Variabel yang Diamati}

Variabel yang diamati yaitu rendemen berdasarkan berat kering (bk) atau dry basis (db) (Sudarmadji et al., 2010), sifat fungsional meliputi daya serap air (Lin et al., 1974 dalam Budijanto et al., 2011), daya serap minyak (Soluski dan Fleming, 1977 dalam Budijanto et al., 2011), swelling volume dan kelarutan (Collado dan Corke, 1999 dalam Wisaniyasa dan Suter, 2016), sedangkan sifat kimia meliputi kadar air, kadar abu, kadar protein, kadar lemak, kadar karbohidrat, dan kadar asam sianida $(\mathrm{HCN})$ (Sudarmadji et al., 2010).

\section{HASIL DAN PEMBAHASAN}

\section{Rendemen Tepung Kacang Koro Benguk dan Tepung Kecambah Kacang Koro Benguk}

Proses perkecambahan berpengaruh sangat nyata $(\mathrm{P}<0,01) \quad$ terhadap rendemen. Rendemen tepung kacang koro benguk dan tepung kecambah kacang koro benguk dapat dilihat pada Tabel 1.
Tabel 1. Rendemen Tepung Kacang Koro Benguk dan Tepung Kecambah Kacang Koro Benguk

\begin{tabular}{lccc}
\hline Parameter & $\begin{array}{c}\text { Tepung } \\
\text { Kacang Koro } \\
\text { Benguk }\end{array}$ & $\begin{array}{c}\text { Tepung } \\
\text { Kecambah } \\
\text { Kacang Koro } \\
\text { Benguk }\end{array}$ & $\begin{array}{c}\text { Hasil } \\
\text { T-test }\end{array}$ \\
\hline $\begin{array}{l}\text { Rendemen } \\
(\% \text { bk })\end{array}$ & $78,37 \pm 0,75$ & $63,93 \pm 1,21$ & $* *$ \\
\hline Ket : $* *=$ berpengaruh sangat nyata &
\end{tabular}

Proses perkecambahan berpengaruh sangat nyata $(\mathrm{P}<0,01)$ terhadap rendemen. Tabel 1 menunjukkan bahwa rendemen tepung kacang koro benguk sebesar 78,37\% (bk), sedangkan tepung kecambah kacang koro benguk sebesar $63,93 \%$ (bk). Hal tersebut kemungkinan karena tingginya laju pengeringan pada tepung kecambah disebabkan oleh banyaknya air bebas dalam bahan yang digunakan untuk proses pertumbuhan kecambah kemudian air bebas lepas pada proses pengovenan. Sifat dari air bebas dalam bahan pangan mudah menguap pada proses pengeringan (Winarno, 2004). Proses perkecambahan juga dimulai dengan penyerapan air oleh biji dan keluarnya bakal tanaman dari lembaga yang disertai dengan terjadinya pelunakan jaringan biji dan mobilisasi cadangan makanan ke bagian vegetatif atau lembaga (Pranoto et al., 1990). Proses penyerapan air oleh biji menyebabkan pelunakan jaringan sel biji dan hubungan antar sel semakin merenggang sehingga tahapan pengovenan (penepungan) air bebas semakin mudah menguap dan kecambah mengalami susut berat sehingga menghasilkan rendemen yang lebih kecil.

\section{Sifat Fungsional Tepung Kacang Koro Benguk dan Tepung Kecambah Kacang Koro Benguk}

Proses perkecambahan berpengaruh sangat nyata $(\mathrm{P}<0,01)$ terhadap daya serap air dan daya serap minyak, namun tidak berpengaruh nyata $(\mathrm{P}>0,05)$ terhadap swelling volume dan kelarutan. Sifat fungsional tepung kacang 
koro benguk dan tepung kecambah kacang koro benguk dapat dilihat pada Tabel 2 .

Tabel 2. Sifat Fungsional Tepung Kacang Koro Benguk dan Tepung Kecambah Kacang Koro Benguk

\begin{tabular}{lccc}
\hline Parameter & $\begin{array}{c}\text { Tepung } \\
\text { Kacang } \\
\text { Koro } \\
\text { Benguk }\end{array}$ & $\begin{array}{c}\text { Tepung } \\
\text { Kecambah } \\
\text { Kacang Koro } \\
\text { Benguk }\end{array}$ & $\begin{array}{c}\text { Hasil } \\
\text { T-test }\end{array}$ \\
\hline $\begin{array}{l}\text { Daya } \\
\text { Serap Air } \\
\left(\mathrm{ml} \mathrm{H} \mathrm{H}_{2} \mathrm{~g}\right)\end{array}$ & $1,57 \pm 0,01$ & $1,67 \pm 0,01$ & $* *$ \\
\hline $\begin{array}{l}\text { Daya } \\
\text { Serap }\end{array}$ & $1,98 \pm 0,01$ & $2,17 \pm 0,02$ & $* *$ \\
$\begin{array}{l}\text { Minyak } \\
\text { (ml } \\
\text { minyak/g) }\end{array}$ & & & \\
\hline $\begin{array}{l}\text { Swelling } \\
\text { Volume } \\
\text { (ml/g) }\end{array}$ & $8,29 \pm 0,09$ & $8,68 \pm 0,17$ & $\mathrm{~ns}$ \\
\hline $\begin{array}{l}\text { Kelarutan } \\
\text { (\%) }\end{array}$ & $26,48 \pm 0,47$ & $25,76 \pm 0,14$ & $\mathrm{~ns}$ \\
\hline Ket : ns = tidak berpengaruh nyata \\
$*=$ berpengaruh nyata \\
$* *=$ berpengaruh sangat nyata
\end{tabular}

\section{Daya Serap Air}

Proses perkecambahan berpengaruh sangat nyata $(\mathrm{P}<0,01)$ terhadap daya serap air tepung kecambah kacang koro benguk. Tabel 2 menunjukkan bahwa daya serap air tepung kacang koro benguk sebesar $1,57 \mathrm{ml} \mathrm{H}_{2} \mathrm{O} / \mathrm{g}$, sedangkan tepung kecambah kacang koro benguk sebesar 1,67 $\mathrm{ml} \mathrm{H}_{2} \mathrm{O} / \mathrm{g}$. Hal tersebut kemungkinan karena proses perkecambahan menyebabkan peningkatkan kadar serat pangan dari tepung yang dihasilkan. Menurut Anita (2009), proses perkecambahan mampu meningkatkan kadar serat pangan larut pada tepung kecambah kacang komak dari 15,85\% menjadi $16,62 \%$. Keberadaan serat mempengaruhi daya serap air pada tepung yang dihasilkan karena adanya komponen yang bersifat hidrofilik seperti serat dimana sifat serat yaitu mudah menyerap air (Ali et al., 2016). Kemungkinan lainnya proses perkecambahan menyebabkan pecahnya molukel kompleks menjadi lebih sederhana dan menjadi agak berporous dan agak renggang sehingga lebih mudah menyerap air dan minyak (Chelule et al., 2010). Tepung dengan daya serap air yang tinggi cenderung lebih cepat dihomogenkan (Tam et al., 2004).

\section{Daya Serap Minyak}

Proses perkecambahan berpengaruh sangat nyata $(\mathrm{P}<0,01)$ terhadap daya serap minyak tepung kecambah kacang koro benguk. Tabel 2 menunjukkan bahwa daya serap minyak tepung kacang koro benguk sebesar 1,98 ml minyak/g, sedangkan tepung kecambah kacang koro benguk sebesar 2,17 $\mathrm{ml}$ minyak/g. Hal tersebut kemungkinan karena proses perkecambahan menyebabkan terbentuknya serat pangan. Salah satu sifat serat pangan adalah kemampuannya dalam mengikat air atau minyak (Wisaniyasa et al., 2017). Keberadaan serat yang terbentuk karena proses perkecambahan menyebabkan daya serap air dan daya serap minyak mengalami peningkatan (Adedeji et al., 2014). Penelitian ini didukung Wisaniyasa et al. (2017) yang menyatakan bahwa perkecambahan dapat meningkatkan daya serap minyak tepung kecambah kacang merah. Selain itu, perkecambaha menyebabkan terpecahnya molukel kompleks menjadi lebih sederhana dan agak berporous dan molekul sederhana berbobot massa kecil menjadi agak renggang dan lebih mudah menyerap air dan minyak (Chelule et al., 2010). Daya serap minyak tepung banyak dimanfaatkan untuk menambahkan sifat fungsional produk berbahan baku daging, disamping itu juga digunakan untuk meningkatkan cita rasa dan tekstur (Kusnandar, 2010).

\section{Swelling Volume}

Proses perkecambahan tidak berpengaruh nyata $(\mathrm{P}>0,05)$ terhadap swelling volume tepung kecambah kacang koro benguk. Tabel 2 menunjukkan bahwa swelling volume tepung kacang koro benguk sebesar 8,29 
$\mathrm{ml} / \mathrm{g}$, sedangkan tepung kecambah kacang koro benguk sebesar $8,68 \mathrm{ml} / \mathrm{g}$. Namun, perkecambahan menunjukkan pengaruh tidak nyata terhadap swelling volume tepung kecambah kacang koro benguk. Hal tersebut kemungkinan karena perkecambahan selama 48 jam belum menunjukkan adanya pengaruh secara nyata terhadap swelling volume tepung kecambah kacang koro benguk.

\section{Kelarutan}

Proses perkecambahan tidak berpengaruh nyata $(\mathrm{P}>0,05)$ terhadap kelarutan tepung kecambah kacang koro benguk. Tabel 2 menunjukkan bahwa kelarutan tepung kacang koro benguk sebesar 26,48\%, sedangkan tepung kecambah kacang koro benguk sebesar $25,76 \%$. Kelarutan dan swelling volume merupakan dua hal yang berkaitan pada saat gelatinisasi. Semakin tinggi nilai kelarutan, maka mempermudah dalam pembuatan produk olahan lainnya (Janathan, 2007). Namun, pada penelitian ini perkecambahan tidak berpengaruh nyata terhadap kelarutan tepung kecambah kacang koro benguk. Hal tersebut kemungkinan karena selama proses perkecambahan 48 jam belum menunjukkan adanya pengaruh terhadap kelarutan tepung kecambah kacang koro benguk.

\section{Sifat Kimia Tepung Kacang Koro Benguk dan Tepung Kecambah Kacang Koro Benguk}

Proses perkecambahan berpengaruh sangat nyata $(\mathrm{P}<0,01)$ terhadap kadar air dan kadar abu, berpengaruh nyata $(\mathrm{P}<0,05)$ terhadap kadar lemak dan kadar karbohidrat, namun tidak berpengaruh nyata $(\mathrm{P}>0,05)$ terhadap kadar protein dan kadar HCN. Sifat kimia tepung kacang koro benguk dan tepung kecambah kacang koro benguk dapat dilihat pada Tabel 3.
Tabel 3.Sifat Kimia Tepung Kacang Koro Benguk dan Tepung Kecambah Kacang Koro Benguk

\begin{tabular}{llll}
\hline Parameter & $\begin{array}{l}\text { Tepung } \\
\text { Kacang } \\
\text { Koro } \\
\text { Benguk }\end{array}$ & $\begin{array}{l}\text { Tepung } \\
\text { Kecambah } \\
\text { Kacang Koro } \\
\text { Benguk }\end{array}$ & $\begin{array}{l}\text { Hasil } \\
\text { T-test }\end{array}$ \\
\hline $\begin{array}{l}\text { Kadar Air } \\
(\%)\end{array}$ & $9,49 \pm 0,25$ & $8,10 \pm 0,06$ & $* *$ \\
\hline $\begin{array}{l}\text { Kadar Abu } \\
(\%)\end{array}$ & $3,12 \pm 0,01$ & $2,87 \pm 0,02$ & $* *$ \\
\hline $\begin{array}{l}\text { Kadar } \\
\text { Protein }(\%)\end{array}$ & $36,39 \pm 0,40$ & $36,33 \pm 0,57$ & $\mathrm{~ns}$ \\
\hline $\begin{array}{l}\text { Kadar } \\
\text { Lemak }(\%)\end{array}$ & $14,19 \pm 0,50$ & $10,77 \pm 0,98$ & $*$ \\
\hline $\begin{array}{l}\text { Kadar } \\
\text { Karbohidrat } \\
(\%)\end{array}$ & $36,83 \pm 0,60$ & $41,92 \pm 0,78$ & $*$ \\
\hline $\begin{array}{l}\text { Kadar HCN } \\
(\mathrm{mg} / \mathrm{kg})\end{array}$ & $5,39 \pm 0,001$ & $5,39 \pm 0,0003$ & $\mathrm{~ns}$ \\
\hline $\begin{array}{l}\text { Ket }: \text { ns }=\text { tidak berpengaruh nyata } \\
*=\text { berpengaruh nyata } \\
* * \text { berpengaruh sangat nyata }\end{array}$ &
\end{tabular}

\section{Kadar Air}

Proses perkecambahan berpengaruh sangat nyata $(\mathrm{P}<0,01)$ terhadap kadar air tepung kecambah kacang koro benguk. Tabel 3 menunjukkan bahwa kadar air tepung kacang koro benguk sebesar $9,49 \%$ dan tepung kecambah kacang koro benguk sebesar $8,10 \%$. Hal tersebut kemungkinan disebabkan karena terjadi proses hidrolisis selama proses perkecambahan berlangsung yaitu proses pemecahan molekul kompleks menjadi senyawa yang lebih sederhana. Proses hidrolisis melibatkan air sehingga kandungan air di dalam bahan berkurang (Ashari, 1995). Penelitian lain juga menyatakan terjadinya penurunan kadar air pada tepung kecambah kedelai sebesar $6,36 \%$ dibandingkan tepung kedelai sebesar 6,71\% (Hazmi, 2016).

\section{Kadar Abu}

Kadar abu dalam bahan menunjukkan jumlah mineral yang dikandungnya. Kacangkacangan mengandung mineral seperti kalsium, besi, tembaga, seng, kalium, dan magnesium. Proses perkecambahan 
berpengaruh sangat nyata $(\mathrm{P}<0,01)$ terhadap kadar abu tepung kecambah kacang koro benguk. Tabel 3 menunjukkan bahwa kadar abu tepung kacang koro benguk sebesar $3,12 \%$ dan tepung kecambah kacang koro benguk sebesar 2,87. Hal tersebut kemungkinan disebabkan karena mineral digunakan dalam metabolisme pertumbuhan kecambah. Menurut Winarno et al. (1980), selama perkecambahan beberapa mineral dilepaskan dan larut dalam media perkecambahan yang menyebabkan penurunan kadar abu. Penelitian lain juga menyatakan adanya penurunan kadar abu pada kacang komak dari 4,32\% menjadi $4,19 \%$ dengan adanya perlakuan perkecambahan (Anita, 2009).

\section{Kadar Protein}

Proses perkecambahan tidak berpengaruh nyata $(\mathrm{P}>0,05)$ terhadap kadar protein tepung kecambah kacang koro benguk. Tabel 3 menunjukkan bahwa kadar protein tepung kacang koro benguk sebesar 36,39\% dan tepung kecambah kacang koro benguk sebesar $36,33 \%$. Hal tersebut kemungkinan karena proses perkecambahan menyebabkan terpecahnya senyawa protein menjadi asam amino. Pengujian kadar protein menggunakan metode Mikro-Kjeldahl dimana menghitung total $\mathrm{N}$ pada produk. Senyawa protein mengandung unsur Nitrogen $(\mathrm{N})$ yang kemudian dipecah menjadi asam amino, sedangkan dalam rumus molekulnya asam amino juga mengandung unsur Nitrogen $(\mathrm{N})$ sehingga hasil yang diperoleh menunjukkan tidak berpengaruh nyata. Selain itu, kemungkinan disebabkan karena perkecambahan selama 48 jam belum menunjukkan adanya pengaruh terhadap kadar protein tepung.

\section{Kadar Lemak}

Proses perkecambahan berpengaruh nyata $(\mathrm{P}<0,05)$ terhadap kadar lemak tepung kecambah kacang koro benguk. Tabel 3 menunjukkan bahwa kadar lemak tepung kacang koro benguk sebesar $14,19 \%$ dan tepung kecambah kacang koro benguk sebesar 10,77\%. Hal ini disebabkan karena proses perkecambahan menyebabkan terjadinya perombakan lemak yang diubah menjadi energi (Mubarak, 2005). Hal tersebut didukung oleh penelitian Hazmi (2016) yang menyatakan bahwa terjadi penurunan kadar lemak pada tepung kecambah kedelai sebesar 23,36\% dibandingkan dengan tepung kedelai sebesar 38,65\%. Penelitian lain juga menyatakan adanya penurunan kadar lemak pada tepung kecambah kacang merah sebesar $6,22 \%$ dibandingkan dengan tepung kacang merah sebesar $6,60 \%$ (Wisaniyasa dan Suter, 2016).

\section{Kadar Karbohidrat}

Proses perkecambahan berpengaruh nyata $(p<0,05)$ terhadap kadar karbohidrat tepung kecambah kacang koro benguk. Tabel 3 menunjukkan bahwa kadar karbohidrat tepung kacang koro benguk sebesar 36,83\% dan tepung kecambah kacang koro benguk sebesar 41,92\%. Hal tersebut kemungkinan disebabkan kadar karbohidrat yang terhitung adalah sebagai serat. Serat merupakan bagian dari tumbuhan yang dapat dikonsumsi dan termasuk dari bagian karbohidrat (Sudargo et al., 2018). Menurut Anita (2009), proses perkecambahan mampu meningkatkan kadar serat pangan larut pada tepung kecambah kacang komak dari 15,85\% menjadi $16,62 \%$. Selain itu, metode pengujian yang digunakan adalah Carbohydrate by different yaitu hasil selisih antara 100\% dengan jumlah antara kadar air, kadar abu, kadar protein, dan kadar lemak. Kadar karbohidrat yang masih sangat besar pada tepung kecambah kacang koro benguk disebabkan adanya penurunan kadar air, kadar abu, dan terutama kadar lemak yang cukup tinggi. Menurut Donangelo et al. (1995) menyatakan bahwa pengaruh perkecambahan setiap kacang-kacangan 
menghasilkan kandungan karbohidrat yang berbeda-beda.

\section{Kadar Asam Sianida (HCN)}

Proses perkecambahan tidak berpengaruh nyata $(\mathrm{P}>0,05)$ terhadap kadar asam sianida (HCN) tepung kecambah kacang koro benguk. Tabel 3 menunjukkan bahwa kadar HCN pada tepung kacang koro benguk sebesar $5,39 \mathrm{mg} / \mathrm{kg}$ dan tepung kecambah kacang koro benguk sebesar 5,39 $\mathrm{mg} / \mathrm{kg}$. Perkecambahan selama 48 jam ternyata belum menunjukkan adanya penurunan kadar $\mathrm{HCN}$. Namun, apabila dibandingkan dengan kadar HCN kacang koro benguk sebesar 16,19 $\mathrm{mg} / \mathrm{kg}$, tepung kacang koro benguk dan tepung kecambah kacang koro benguk mengalami penurunan. Penurunan kadar $\mathrm{HCN}$ kemungkinan dikarenakan proses perendaman yang dilakukan pada proses pembuatan tepung kacang koro benguk maupun tepung kecambah kacang koro benguk. Sianida mempunyai sifat fisik mudah larut dalam air (Suryani dan Wesniati, 2000). Menurut Winarno (2004), perendaman dengan air dapat merombak HCN dari ikatan glikosida sianogenik, sehingga $\mathrm{HCN}$ banyak yang larut dan terbawa oleh air.

\section{SIMPULAN DAN SARAN}

\section{Simpulan}

Berdasarkan hasil penelitian dapat disimpulkan bahwa:

1. Perkecambahan kacang koro benguk berpengaruh sangat nyata terhadap rendemen, daya serap air, daya serap minyak, kadar air, dan kadar abu, berpengaruh nyata terhadap kadar lemak dan kadar karbohidrat, namun tidak berpengaruh nyata terhadap swelling volume, kelarutan, kadar protein, dan kadar $\mathrm{HCN}$.

2. Tepung kecambah kacang koro benguk mempunyai rendemen sebesar 63,93\% (bk), sifat fungsional yaitu daya serap air sebesar $1,67 \mathrm{ml} \mathrm{H} 2 \mathrm{O} / \mathrm{g}$, daya serap minyak sebesar $2,17 \mathrm{ml} \mathrm{minyak/g}$, swelling volume sebesar 8,68 $\mathrm{ml} / \mathrm{g}$, kelarutan sebesar $25,76 \%$, sedangkan sifat kimia yaitu kadar air sebesar 8,10\%, kadar abu sebesar 2,87\%, kadar protein sebesar 36,33\%, kadar lemak sebesar 10,77\%, kadar karbohidrat sebesar 41,92\%, dan kadar $\mathrm{HCN}$ yaitu $5,39 \mathrm{mg} / \mathrm{kg}$.

\section{Saran}

Berdasarkan hasil penelitian disarankan untuk adanya penelitian lebih lanjut mengenai masa simpan dan aplikasi tepung kecambah kacang koro benguk pada produk pangan.

\section{DAFTAR PUSTAKA}

Adedeji, O. E., O.D. Oyinloye, and O.B. Ocheme, 2014. Effects of Germination Time on the Functional Properties of Maize Flour and the Degree of Gelatinization of Its Cookies. Afr. Journal of Food Science. 8(1):42-47.

Ali, A., T.T. Wani, I.A. Wani, and F.A. Masoodi. 2016. Comparative Study of The Physico- Chemical Properties of Rice and Corn Starches Grown in Indian Temperate Climate. Journal of the Saudi Society of Agricultural Sciences. 15(1):75-82.

Anita, S. 2009. Studi Sifat Fisikokimia Sifat Fungsional Karbohidrat Dan Aktivitas Antioksidan Tepung Kecambah Kacang Komak (Lablab purpureus (L) Sweet). Skripsi. Tidak dipublikasikan. Institut Pertanian Bogor. Bogor.

Anonimus. 2006. Standar Nasional Indonesia (SNI). SNI 01-7152-2006. Bahan Tambahan Pangan - Persyaratan Perisa dan Penggunaan dalam Produk Pangan. Dewan Standarisasi Nasional. Jakarta. 
Ashari. 1995. Hortikultura Aspek Budidaya. Penerbit Universitas Indonesia, Jakarta.

Budijanto, S., A.B. Sitanggang, dan W. Murdiati. 2011. Karakteristik Sifat Fisiko-Kimia dan Fungsional Isolat Protein Biji Kecipir (Psophocarpus tetragonolobus L.). Jurnal Teknologi dan Industri Pangan. XXII(2):130-136.

Chelule, P.K., M.P. Mokoena, and N. Galeni. 2010. Advantages of Traditional Lactic Acid Bacteria Fermentation of Food in Africa. Current Research, Technology and Education Topics in Applied Microbiology and Microbial Biotechnology. 2:1160-1167.

Donangelo C.M., L.C. Trugo, N.M.F. Trugo, and B.O. Eggum. 1995. Effect of Germination of Legume Seeds on Chemical Composition and Energy Utilization in Rats. Journal of Food Chemistry. 53(1):23-27.

Hazmi, K. 2016. Karakteristik Fisikokimia Tepung Kecambah Kedelai dan Tepung Kedelai. Skripsi. Tidak dipublikasikan. Institut Pertanian Bogor, Bogor.

Janathan. 2007. Karakteristik Fisikokimia Tepung Bekatul Serta Optimasi Formula dan Pendugaan Umur Simpan Minuman Campuran Susu Skim dan Tepung Bekatul. Skripsi. Tidak dipublikasikan. Institut Pertanian Bogor, Bogor.

Kanetro, B. dan S.H.C. Dewi. 2010. Pengembangan Protein Kecambah Kacang-Kacangan Lokal sebagai Bahan Dasar Meat Analog dan Potensinya dalam Memberikan Efek Hipokolesterolemik dan Hipoglisemik. Laporan Penelitian Hibah Besaing
Dirjen Dikti. Universitas Mercu Buana, Yogyakarta.

Khairi, E., dan B. Kanetro. 2014. Pengaruh Berbagai Kecambah Kacang-Kacangan terhadap Kadar Protein Terlarut dan Asam Amino Bebas Limbah Cair Isolasi Protein. Jurnal Agrisains. 5(2):102-114.

Kristianto, A. 2013. Karakteristik Fisikokimia dan Sifat Fungsional Tepung Koro Benguk (Mucuna pruriens L.) Berprotein Tinggi. Skripsi. Tidak dipublikasikan. Institut Pertanian Bogor, Bogor.

Kusnandar, F. 2010. Komponen Makro Kimia Pangan. Dian Rakyat, Jakarta.

Metirukmi, D. 1992. Peranan Kedelai dan Hasil Olahanya dalam Penanggulangan Masalah Gizi Ganda. Makalah disampaikan dalam Seminar Pengembangan Teknologi Pangan dan Gizi Menyongsong Pelita VI, Bogor, 19 Desember 1992.

Mubarak A.E. 2005. Nutritional Composition and Antinutritional Factors of Mungbean Seeds (Phaseolus aureus) as Affected by Some Home Traditional Processes. Journal of Food Chemistry. 89(4):489-495.

Pranoto, H.S., W.Q. Mugnisjah, dan E. Murniati. 1990. Biologi Benih. Pusat Antar Universitas, Bogor.

Steel, R.G. and J.H. Torrie. 1995. Prinsip dan Prosedur Statistika. Diterjemahkan oleh Bambang Sumantri. PT. Gramedia, Jakarta. 
Sudargo, T., H. Freitag, N.A. Kusmayanti, dan F. Rosiyani. 2018. Pola Makan dan Obesitas. UGM Press, Yogyakarta.

Sudarmadji S., B. Haryono dan Suhardi. 2010. Prosedur Analisa untuk Bahan Makanan dan Pertanian. Edisi Kedua Penerbit Liberty, Yogyakarta.

Suryani dan Wesniati. 2000. Studi Pembuatan Tepung Kara Benguk. Prosiding Seminar Teknologi Pertanian Spesifik Lokasi dalam Upaya Peningkatan Kesejahteraan Petani dan Pelestarian Lingkungan, Yogyakarta.

Syam, A. 2003. Sistem Pengelolaan Lahan Kering di Daerah Aliran Sungai Bagian Hulu. Jurnal Litbang Pertanian. 22(4):162-171.

Tam, L.M.H., W.T. Corke, J. Tan J, Li, and L.S. Collado. 2004. Production of Bihon-Type Noodle from Maize Starch Differing In Amylosa Content. J. Cereal Chem. 81(4):475-480.

Winarno, F.G., S.S. Endang, dan A.B. Ahza. 1980. Mempelajari Pengaruh Proses Perkecambahan Biji-bijian terhadap Sifat Fisik dan Kimia Rendemen Tepung. Bogor: Bul. FTDC-IPN.

Winarno, F.G. 2004. Kimia Pangan dan Gizi. PT. Gramedia, Jakarta.

Wisaniyasa, N.W., I.K. Suter, Y. Marsono, and I.N.K. Putra. 2015. Germination Effect on Functional Properties and Antitrypsin Activities of Pigeon Pea (Cajanuscajan (L.,) Millsp.) Sprout Flour. Journal of Food Technology. 43(10):79-83.

Wisaniyasa, N.W. dan I.K. Suter. 2016. Kajian Sifat Fungsional dan Kimia
Tepung Kecambah Kacang Merah (Phaseolus vulgaris 1.). Media Ilmiah Teknologi Pangan. 3(1):26-34.

Wisaniyasa, N.W., A.S. Duniaji, dan A.A.G.N.A. Jambe. 2017. Studi Daya Cerna Protein, Aktivitas Antioksidan dan Sifat Fungsional Tepung Kecambah Kacang Merah (Phaseolus vulgaris L.) Dalam Rangka Pengembangan Pangan Fungsional. Media Ilmiah Teknologi Pangan. 4(2):122-129. 